Jean Senise Pimenta jspimenta@hotmail.com

\author{
Augusto J. A. Buschinelli \\ buschi@emc.ufsc.br \\ Federal University of Santa Catarina \\ Department of Mechanical Engineering \\ 88040-970 Florianopolis, SC, Brazil
}

\section{Rubens M. do Nascimento}

\author{
Antônio Eduardo Martinelli \\ Federal University of Rio Grande do Norte \\ Department of Mechanical Engineering \\ 59072-970 Natal, RN, Brazil \\ Josef Remmel \\ Forschungszentrum Juelich - ZAT \\ D 52425 Juelich, Germany
}

\section{Brazing of Metals to Zirconia} Mechanically Metallized with Titanium

The mechanical metallization is a successful technique at laboratory scale and specially applied to oxide ceramics. Indirect brazing process of zirconia to metals is achieved using active-metal-free filler alloys on previously metallized ceramic. Stabilized zirconia ceramics were mechanically metallized with Ti and wetting conditions evaluated using commercial $\mathrm{Ag}-\mathrm{Cu}$ and $\mathrm{Au}$-Ni fillers with its respective thermal cycles. Better results were selected for brazing ceramic to metals in a high-vacuum furnace. Reliable vacuum tight ceramic/metal joints were obtained specially using the $\mathrm{Ag}$-28Cu filler for results below 10-

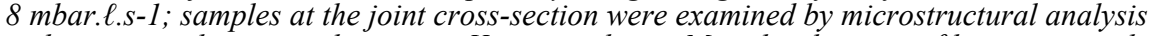
techniques and energy dispersive X-ray analysis. Microhardness profiles were made across the joints interface where zirconia undergone a typical darkening effect during brazing. Microstructure at the braze region revealed a dark reaction layer and precipitation zone closely to metallized ceramic surface for zirconia/Ti-6Al4V joints due to chemical interactions between the individual components.

Keywords: mechanical metallization, brazing, ceramic-metal joining

\section{Introduction}

The progressive development of advanced ceramics could be associated to an increased demand for joining ceramics to themselves or to metals for producing hybrid components with reliable interfaces and improved engineering properties. Advanced ceramics include oxides, carbides, nitrides and a number of their composites. In fact, alumina and zirconia $\left(\mathrm{ZrO}_{2}\right)$ have been the most commonly investigated oxide ceramics for researchers aiming possibilities of industrial applications when joined with other materials (Liu et al., 2009). Moreover, zirconia exhibits higher strength and fracture toughness than alumina particularly at temperatures below $\approx 300^{\circ} \mathrm{C}$ for $K_{\text {IC }}$ values in the range $15-20 \mathrm{MPa}^{1 / 2}$ (Hanson et al., 2000). These properties are beneficial in many technical applications from wire drawing dies, cutting and machining tools, gas turbines to oxygen sensors and solid oxide fuel cells, including those that require the ceramic to be bounded to a metallic member (Sciti et al., 2001; Smorygo et al., 2007).

Active metal brazing is the most common method for joining ceramics to metals in which is used filler alloy that contain a few percents of a reactive metal in its composition, such as $\mathrm{V}, \mathrm{Cr}, \mathrm{Ta}$, $\mathrm{Hf}, \mathrm{Zr}$ and specially Ti. These solutes promote lower contact angles and enhance the ceramic/metal wettability by reducing the oxide that constitutes the main ceramic phase (Muolo et al., 2004; Singh et al., 2007; Liu et al., 2009). Formation of a continuous interfacial reaction layer between the ceramic and fillers is an important factor for joint strength (Smorygo et al., 2007). Ceramic is joined to metallic member by chemical reactions at the joint during brazing temperature. However, higher costs of these fillers have driven forward alternative joining approaches such as previous metallization on the ceramic surface with an active metal for subsequent indirect brazing using active-metal free filler alloys (Nascimento et al., 2002).

Paper accepted May, 2010. Technical Editor: Anselmo Eduardo Diniz.
Several techniques used for previous ceramic metallization that are well-documented in the scientific literature, such as physical and chemical vapour deposition (PVD and CVD process, respectively), have nevertheless the handicap of being more expensive and laborious than the here proposed mechanical metallization. On the other side, the well-known Mo-Mn process is inappropriate for zirconia metallization because it does not have a glassy intergranular phase, which is a key factor for joining between the formed metallic film and ceramic substrate (Hanson et al., 2000). In the Mo-Mn process a paint of Mo and Mn powder or of their oxide powders is applied to an oxide ceramic surface $\left(\mathrm{Al}_{2} \mathrm{O}_{3}\right.$ or $\mathrm{BeO}$, for example) and fired in $\mathrm{H}_{2}$ of a controlled dew point; the Mo sinters to form a porous metal coating and the $\mathrm{MnO}$ reacts with the $\mathrm{SiO}_{2}$ containing ceramic to form a glassy phase of controlled viscosity which penetrates into the Mo coating - this coating is electroplated with $\mathrm{Ni}$ on which the filler alloy spreads easily (Elssner and Petzow, 1990).

The mechanical metallization technique has been in continuous development, involving studies about oxide and non-oxide ceramics to produce reliable vacuum tight ceramic/metal joints with low cost production (Nascimento, 2001 and 2002). It has been observed that the typical microstructure at the interface is characterized by eutectic constituent close to a rich-Ti reaction layer and eventually by a precipitation zone between them (Nascimento et al., 2002; Nascimento, 2007).

Filler alloy previously selected must also prevent grain growth and long-term thermomechanical degradation due to creep and oxidation, and have its coefficient of thermal expansion (CTE) closely matched with the brazed materials (Singh et al., 2007). As well as with the filler, it is also crucial avoiding CTE mismatch for individual components to be joined. For instance, partially stabilized zirconia and Ti-6Al-4V (ASTM Grade 5) have similar CTE values $\left(\approx 10 \times 10^{-6} /{ }^{\circ} \mathrm{C}\right.$ and $9,7 \times 10^{-6} /{ }^{\circ} \mathrm{C}$ respectively). Copper member $(\approx 17$ $\times 10^{-6} /{ }^{\circ} \mathrm{C}$ ) can be joined to ceramic because it is able to undergo enough interfacial plastic flow to accommodate residual stresses produced at the joint interface (Nascimento, 2001). Other important consideration is that fillers must have liquidus temperature greater than work temperature of the joint, but lower than component's 
melting temperature. The eutectic $\mathrm{Ag}-\mathrm{Cu}$ based filler is generally preferred for joining ceramic to metals because it is ductile and chemically inert, which reduces the oxidation and therefore minimizes residual stresses during cooling from brazing temperature (Sciti et al., 2001; Singh et al., 2008). In addition, zirconia stabilized with yttria or magnesia is wet and strongly bonded by Ag-Cu based filler even with small $\mathrm{Ti}$ percents in its composition (commercially 1.5-4.5 wt.\% Ti) (Sciti et al., 2001).

In the present study, the mechanical metallization with $\mathrm{Ti}$ on the ceramic surface was a previous stage for brazing zirconia to metals using commercial active-metal-free filler alloys. Producing reliable vacuum tight brazing joints based on knowledge about wetting behavior for both analyzed zirconia ceramics and characterizing the resultant microstructure at the ceramic/metal interface were the main objectives in this study. And evaluating how the darkening effect in zirconia affects its hardness property at the brazed joint interface.

\section{Experimental Procedures}

Ceramic materials rods $\varnothing 8.0 \mathrm{~mm}$ were tetragonal zirconia polycristals with yttria 5-10 wt.\% (TZP-Y) and partially stabilized zirconia with magnesia 3-4.5 wt.\% (PSZ-Mg) from Engecer Ltda./Brazil. Metallic counterparts were Cu-ETP (DIN EN 13601) and Ti-6Al-4V (ASTM Grade 5, annealed); conical-shape tools used for mechanical metallization process were produced from a rod of commercially pure Ti (ASTM Grade 2). Filler alloys were VH780 $(\mathrm{Ag}-28 \mathrm{Cu})$ and VH950 (Au-18Ni). Table 1 shows properties of the materials used in this study, according to the manufacturers.

Zirconia samples $\left(\mathrm{ZrO}_{2}\right)$ were polished to $1 \mu \mathrm{m}$ diamond and ultrasonically cleaned in acetone bath for 10 minutes before its metallization. Ti-6Al-4V alloy members were cleaned with ethanol to remove machining residues; copper members were first cleaned in a bath $5 \% \mathrm{HNO}_{3}$ to remove superficial oxides and later ultrasonically cleaned in ethanol.

Figure 1 shows a schematic illustration of the mechanical metallization process. Ceramic samples are attached to the lathe and turn on the counterclockwise under constant speed ( $800 \mathrm{rpm})$, while the conical-shape tool is attached to a reworking high speed that turn on the clockwise $(27,000 \mathrm{rpm})$. During the contact between these two components, the metallic tool wears out and a titanium coating is deposited on the ceramic surface. This particular metallization is made at room temperature with low cost production and environmentally safe, because it does not produce hazardous chemical residues. Nascimento (2001) established the main control parameters for this metallization process; oxidation behavior was not detected for metallization under previously specified conditions.

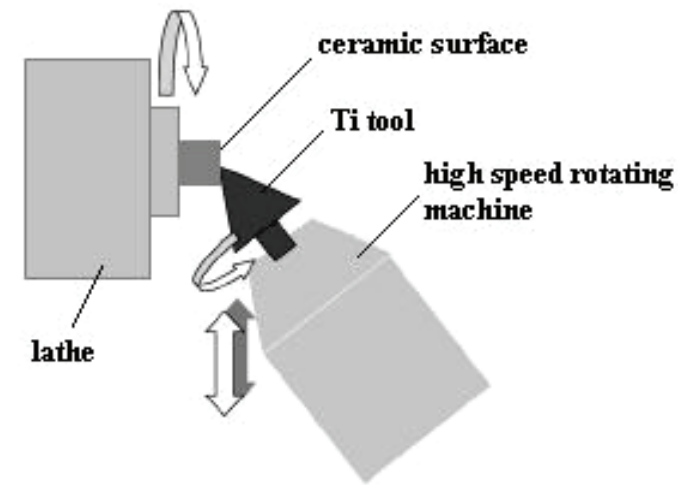

Figure 1. Schematic illustration of the mechanical metallization process (adapted from Nascimento, 2001).
Wetting tests were made in a high-vacuum furnace at FZ-Juelich (PFEIFFER MOV262) with samples mechanically metallized with $\mathrm{Ti}$, using two different wetting temperatures (soaking for 10 minutes) for each commercial filler alloy: $820^{\circ} \mathrm{C}$ and $880^{\circ} \mathrm{C}$ for $\mathrm{VH} 780(\mathrm{Ag}-28 \mathrm{Cu})$ filler; $980^{\circ} \mathrm{C}$ and $1050^{\circ} \mathrm{C}$ for $\mathrm{VH} 950(\mathrm{Au}-18 \mathrm{Ni})$ filler. Working temperatures for VH780 and VH950 fillers are respectively $780-820^{\circ} \mathrm{C}$ and $970^{\circ} \mathrm{C}$, according to the manufacturer. Contact angles were measured when samples were removed from the vacuum furnace in the end of wetting tests by software developed at UFRN (Brazil) using images analysis. Wetting conditions were also qualitatively analyzed by microstructural analysis techniques at the ceramic/filler interface; better results were selected for brazing tests. The standard thermal cycle used for both wetting and brazing tests is shown in Fig. 2: there are two levels for temperature homogenization $\left(700^{\circ} \mathrm{C}\right.$ and $\left.750^{\circ} \mathrm{C}\right)$; third level is specific for wetting and subsequent brazing temperature.

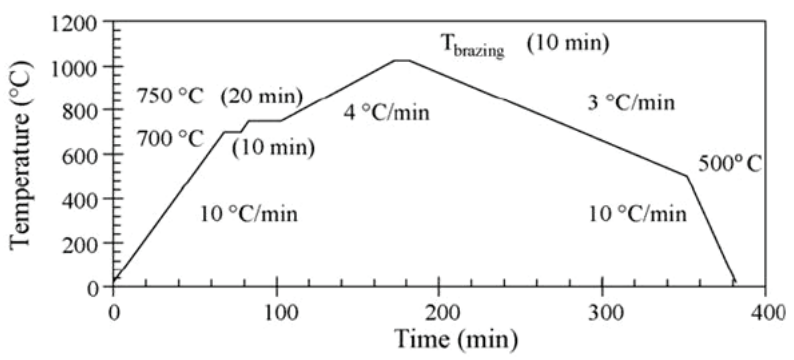

Figure 2. Standard thermal cycle used for wetting and brazing tests.

Each joint assemble was submitted to a normal load approximately $120 \mathrm{kPa}$ on its top. Brazing ceramic to metals was made using a simple butt-joint configuration in a high-vacuum furnace (better than $3 \times 10^{-5} \mathrm{mbar}$ ), which was also useful for He gas leak tests at room temperature (Inficon UL200 equipment), according to the scheme shown in Fig. 3.

Samples were selected for microestructural analysis from tight ceramic/metal joints: mounted in epoxy and cut on a low-speed diamond wire, submitted to final polishing with $0,025 \mu \mathrm{m} \mathrm{SiO}_{2}$ particles suspension. Cross-section at the joint interface was analyzed by optical and scanning electron microscopy (SEM) Cambridge Stereoscan 360 equipped with linescan technique by energy dispersive X-ray analysis (EDX) and operating voltage of 20 $\mathrm{kV}$. Microhardness measurements were done using a Vickers microindenter on a Shimadzu HMV-2 machine (load of $200 \mathrm{~g}$ for $10 \mathrm{~s}$ ).

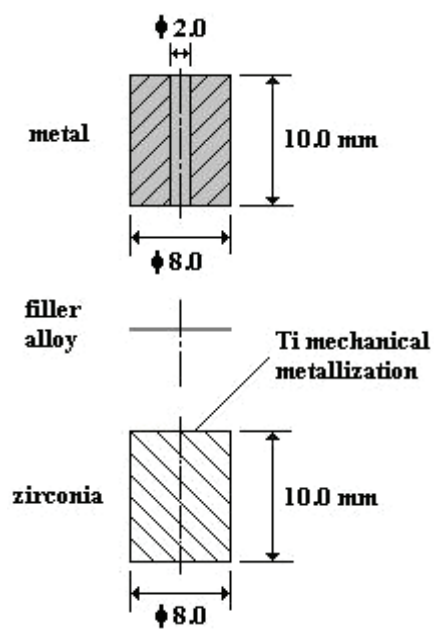

Figure 3. Brazing joints configuration also used for helium gas leak tests. 
Table 1. Properties of the materials used for joining ceramic to metals.

\begin{tabular}{|c|c|c|c|c|}
\hline Component / Properties & TZP-Y & PSZ-Mg & Ti-6Al-4V & Cu-ETP \\
\hline Purity / Composition (\%wt.) & $\begin{array}{c}\text { 99.0-99.2\% / } \\
\text { 5.0-10.0\%wt. } \mathrm{Y}_{2} \mathrm{O}_{3}, \mathrm{ZrO}_{2} \text { balance }\end{array}$ & $\begin{array}{c}99.0-99.2 \% / \\
\text { 3.0-4.5\%wt. } \mathrm{MgO}_{2} \mathrm{ZrO}_{2} 90.0-95.0 \% \text {, others }\end{array}$ & $\begin{array}{l}\text { ASTM } \\
\text { Grade } 5\end{array}$ & $\begin{array}{c}99.9 \% \mathrm{Cu}, \\
0.005-0.04 \% \text { ODIN EN } 13601\end{array}$ \\
\hline $\begin{array}{l}\text { Apparent density } \\
\text { at } 20^{\circ} \mathrm{C}\left(\mathrm{g} / \mathrm{cm}^{3}\right)\end{array}$ & $5.5-6.1$ & $5.1-5.6$ & 4.43 & 8.93 \\
\hline Linear CTE $\left(10^{-6}{ }^{\circ} \mathrm{C}^{-1}\right)$ & $10.4\left(25-1000^{\circ} \mathrm{C}\right)$ & $10.0-10.1\left(25-1000^{\circ} \mathrm{C}\right)$ & $9.7\left(20-650^{\circ} \mathrm{C}\right)$ & $17.7\left(20-300^{\circ} \mathrm{C}\right)$ \\
\hline E modulus $(\mathrm{GPa})$ & 206 & 204 & 113.8 & 130 \\
\hline
\end{tabular}

\section{Results and Discussion}

\section{Wetting Tests and Brazing Conditions}

Initially, zirconia samples were mechanically metallized with $\mathrm{Ti}$ and wetting behavior was investigated using two different filler alloys for two thermal cycles. These alloys dissolved part of this coating and its active metal reacted with the oxide ceramic to improve wetting on its surface at brazing temperature. Table 2 shows summarized results and selected wetting conditions for subsequence brazing tests. Results for both zirconia ceramics were better with the eutectic $\mathrm{Ag}-28 \mathrm{Cu}$ filler alloy than with $\mathrm{Au}-18 \mathrm{Ni}$ filler. There were partial wetting conditions using Au-18Ni filler alloy, but spreading on the metallized surface was not efficient for both zirconia ceramics. Although wetting results had not been so favorable for it, the former condition for it (see shaded area at $980^{\circ} \mathrm{C}$ ) was also investigated for subsequent brazing tests. There was no adherence of melted $\mathrm{Au}-18 \mathrm{Ni}$ filler alloy on the substrate for tests at $1050^{\circ} \mathrm{C}$.

Results were qualitatively evaluated and contact angles measured when samples were removed from vacuum furnace: for wetting tests with $\mathrm{Au}-18 \mathrm{Ni}$ filler - values were in the range $35^{\circ}-40^{\circ}$ for tests at $980^{\circ} \mathrm{C}$. For tests with $\mathrm{Ag}-28 \mathrm{Cu}$ filler there was visually total wetting on the metallized ceramic with contact angles $\approx 0^{\circ}$.

\section{Helium Gas Leak Detection at the Brazed Joints}

Brazed joints were submitted to a helium gas leak detector at room temperature. Table 3 shows summarized results for these tests, in which leak rates bellow than $10^{-8}$ mbar.. $\mathrm{s}^{-1}$ were considered totally satisfactory. Titanium was efficient as active metal for both mechanically metallized zirconia ceramics. Even though some wetting tests had been classified as partial (see previous Table 2), leak rates results were also satisfactory for $\mathrm{ZrO}_{2} / \mathrm{Au}-18 \mathrm{Ni} / \mathrm{Cu}$ joints. Some samples from these reliable vacuum tight joints were examined by conventional microstructural techniques.

Leak rate results for zirconia/Au-18Ni/Ti-6Al-4V joints were not satisfactory. Most of these joint assembles were weakly brazed after they had been removed from the vacuum furnace. He gas leak detection was possible in a few of them, in which brazed joints exhibited leak rates too much high $\left(>10^{-4}\right.$ mbar.l. $\left.\mathrm{s}^{-1}\right)$. Possible explanations for this situation are: poor wetting behavior of the $\mathrm{Au}-$ $18 \mathrm{Ni}$ filler on the mechanically metallized ceramic surface had already been previously verified; and an excessive formation of intermetallic compounds in the microstructure at the ceramic/metal interface. Samples were also selected for microstructural analysis.

Schröder et al. (2000) consider that the allowable maximum leak rate for most cases of technical application is in the range $10^{-6}-10^{-8}$ mbar.. $\mathrm{s}^{-1}$; leak rate values bellow $10^{-8}$ mbar. $\ell . \mathrm{s}^{-1}$ can classify vacuum tight components, which means there would be approximately $3 \mathrm{ml}$ of $\mathrm{He}$ gas loss in 1 year with a discontinuity diameter of $\approx 0,4 \mu \mathrm{m}$. They also suggested that leak values around $10^{-3}$ mbar. $\ell . \mathrm{s}^{-1}$ means one air bubble loss per second $\left(\approx 1 \mathrm{~mm}^{3}\right)$.

Table 2. Summarized results for wetting tests and selected conditions for brazing tests (see gray shaded areas).

\begin{tabular}{|c|c|c|c|c|c|}
\hline \multirow{4}{*}{ Zirconia } & \multirow{4}{*}{ Active metal } & \multicolumn{4}{|c|}{ Filler alloy } \\
\hline & & \multicolumn{2}{|c|}{ VH780 (Ag-28Cu) } & \multicolumn{2}{|c|}{ VH950 (Au-18Ni) } \\
\hline & & \multicolumn{4}{|c|}{ Wetting temperature, soaking $10 \mathrm{~min}$} \\
\hline & & $820^{\circ} \mathrm{C}$ & $880^{\circ} \mathrm{C}$ & $980^{\circ} \mathrm{C}$ & $1050^{\circ} \mathrm{C}$ \\
\hline \multirow{2}{*}{$\begin{array}{l}\text { TZP-Y, } \\
\text { PSZ-Mg }\end{array}$} & \multirow{2}{*}{$\mathrm{Ti}$} & $\mathrm{OK}$ & $\mathrm{OK}$ & partial wetting $^{(1)}$ & \multirow{2}{*}{ No adherence } \\
\hline & & OK & $\mathrm{OK}$ & partial wetting $^{(1)}$ & \\
\hline
\end{tabular}

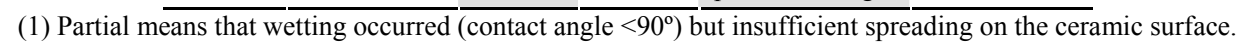

Table 3. Summarized results of helium gas leak tests at the brazed ceramic/metal joints.

\begin{tabular}{cccc}
\hline \multicolumn{3}{c}{ Brazing temperature at $820^{\circ} \mathrm{C}$, soaking $10 \mathrm{~min}-\mathrm{VH} 780(\mathrm{Ag}-28 \mathrm{Cu})$} \\
\hline Zirconia & Active metal & ceramic/metal joints & $\begin{array}{c}\text { Leak rates } \\
\left(\mathrm{mbar} . \ell . \mathrm{s}^{-1}\right)\end{array}$ \\
\hline TZP-Y, PSZ-Mg & \multirow{2}{*}{$\mathrm{Ti}$} & zirconia/Ag-28Cu/Cu & $<10^{-8}$ \\
\cline { 3 - 4 } & & zirconia/Ag-28Cu/Ti-6Al-4V & $<10^{-8}$ \\
\hline Brazing temperature at $980^{\circ} \mathrm{C}$, soaking $10 \mathrm{~min}-\mathrm{VH} 950(\mathrm{Au}-18 \mathrm{Cu})$ \\
\hline TZP-Y, PSZ-Mg & $\mathrm{Ti}$ & zirconia/Au-18Ni/Cu & $<10^{-8}$ \\
\cline { 3 - 4 } & & zirconia/Au-18Ni/Ti-6Al-4V & $>10^{-4}$ \\
\hline
\end{tabular}




\section{Microstructural Analysis}

Figure 4 shows a SEM image representative for wetting conditions using $\mathrm{Ag}-28 \mathrm{Cu}$ filler alloy at $820^{\circ} \mathrm{C}$, in which it was produced a continuous reaction layer at the filler/ceramic interface. This layer was not observed at $880^{\circ} \mathrm{C}$ and it was probably diluted in the microstructure of melted filler alloy. Formation of this layer at the interface is considered a key factor to the vacuum tightness and ceramic/metal joint strength (Nascimento et al., 2002; Smorygo et al., 2007). For wetting test using the $\mathrm{Au}-18 \mathrm{Ni}$ filler, there was formed a very thin reaction layer at the filler/ceramic interface at $980^{\circ} \mathrm{C}$ and there was not adherence of this filler on the metallized substrate at $1050^{\circ} \mathrm{C}$. In addition, Fig. 4 also exhibits a continuous dark reaction sublayer that was formed closely to the metallized ceramic surface which is basically composed of Ti-O compounds ( $\mathrm{TiO}, \mathrm{Ti}_{2} \mathrm{O}_{3}$, $\mathrm{Ti}_{3} \mathrm{O}_{5} \ldots \mathrm{TiO}_{2}$ ). It is beneficial to improve wetting on the ceramic substrate by melted filler alloy from superficial reduction of zirconium oxide and precipitation of active metal oxides (Hanson et al., 2000; Sciti et al., 2001; Smorygo et al., 2007; Singh et al., 2008).

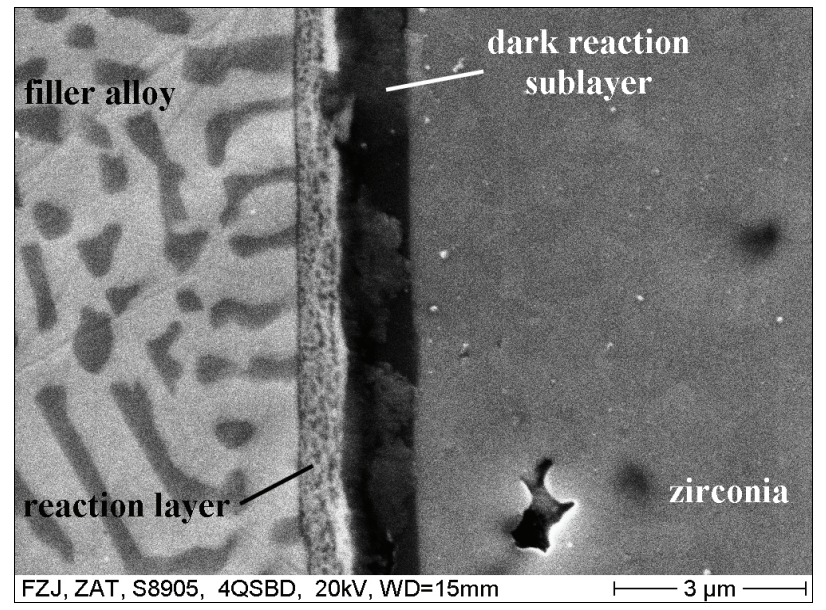

Figure 4. SEM image at $\mathrm{Ag}-28 \mathrm{Cu} / \mathrm{ZrO}_{2}$ interface, wetting test at $820^{\circ} \mathrm{C}$. Reaction layer and a dark sublayer closely to the ceramic surface.

$\mathrm{ZrO}_{2} / \mathrm{Ag}-28 \mathrm{Cu} / \mathrm{Cu}$ joints interface are represented in Fig. 5. Optical micrograph in Fig. 5(a) suggests formation of a sound brazed joint and melted filler alloy is well-diluted with the metallic member (Cu-ETP), which is really good to accommodate residual thermal stresses. SEM image in Fig. 5(b) shows a thin and partially discontinuous reaction layer $(\approx 2 \mu \mathrm{m})$ between the ceramic and the filler, including an adjacent defect area. Reaction layers on mechanically metallized ceramic are usually discontinuous (Nascimento et al., 2002). The adjacent dark area represents a reaction sublayer closely to the metallized ceramic surface and it is basically composed of titanium oxides. Elemental composition profile by linescan technique at the joint cross-section is also shown in Fig. 5(b). There was Ti diffusion from the metallized surface into the ceramic and it is also present in the reaction layer produced above this dark sublayer (rich $\mathrm{Ti}$ zone), including $\mathrm{Ag}, \mathrm{Cu}$ and low levels of EDX analysis for Y and Zr. Intermetallics inclusions were not found here.

Nascimento et al. $(2002,2003)$ concluded that in defect areas on the ceramic surface after previous mechanical metallization with $\mathrm{Ti}$, wetting took place because of melted filler alloy becomes active at brazing temperature. Although the local availability of Ti had been lower in these areas, it was produced a wavy reaction layer on the metallized ceramic surface with reduced thickness (about 2-4 $\mu \mathrm{m}$ ) at the brazed ceramic/metal joint interface.
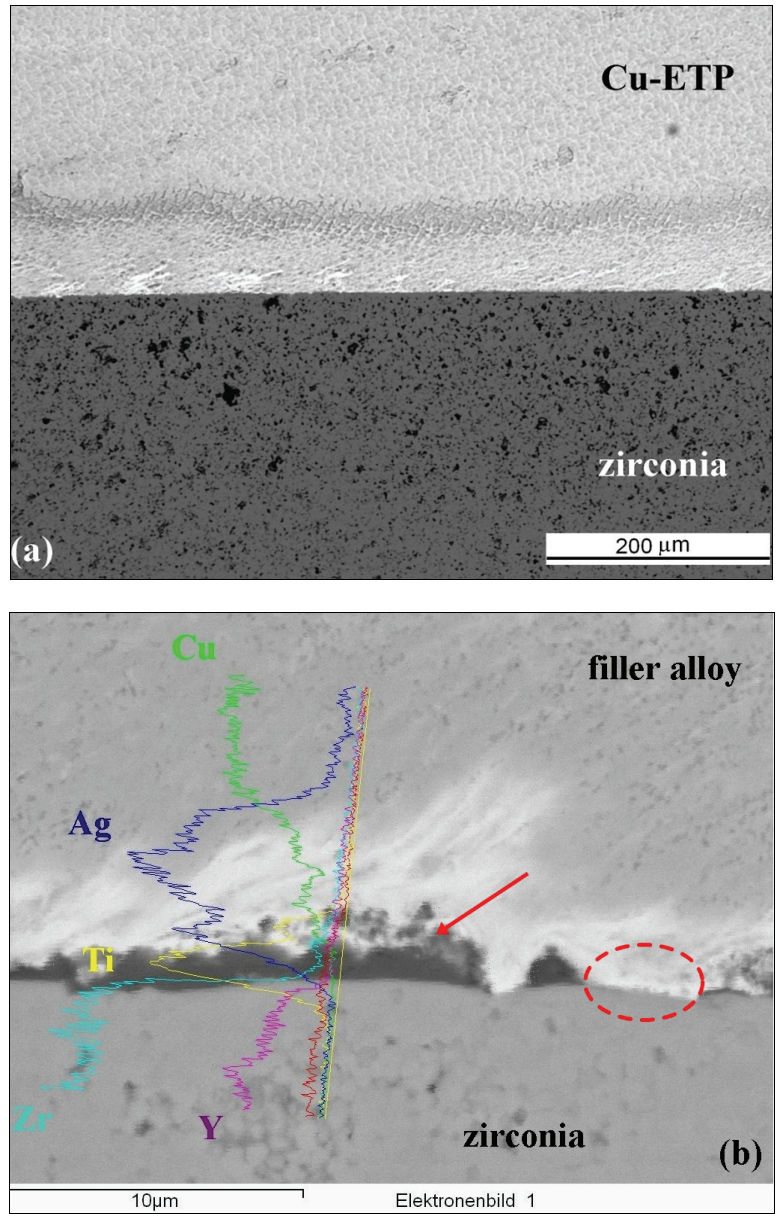

Figure 5. (a) Optical micrograph for TZP-Y/Ag-28Cu/Cu joint (brazing at $820^{\circ} \mathrm{C}$ ); (b) SEM image + linescan technique. Reaction layer at the ceramic/filler interface (see arrow) and defect area (see circle).

Figure 6 represents brazed $\mathrm{ZrO}_{2} / \mathrm{Ag}-28 \mathrm{Cu} / \mathrm{Ti}-6 \mathrm{Al}-4 \mathrm{~V}$ joints at $820^{\circ} \mathrm{C}$. SEM image in Fig. 6a suggests formation of a reliable sound joint showing a precipitation zone at the ceramic/filler interface; there is also a diffusive zone in the metallic member and a reaction layer between the metal and filler alloy. Linescan technique result across the filler/diffusive zone interface revealed that there was diffusion of elemental $\mathrm{Cu}$ and $\mathrm{Ag}$ to the metallic member, and this reaction layer is really an intermetallic layer that contains mainly $\mathrm{Ti}$ and $\mathrm{Cu}$, and lower EDX levels of the elemental $\mathrm{Ag}, \mathrm{Al}$ and $\mathrm{V}$ that indicate formation of a CuTi-rich zone. Possible formation of $\mathrm{CuTi}$ and $\mathrm{CuTi}_{2}$ compounds in these regions is according to the $\mathrm{Cu}-\mathrm{Ti}$ equilibrium phase diagram, because copper has a strong tendency to produce intermetallics with titanium (Hanson et al., 2000; Smorygo et al., 2007). Figure 6(b) shows an elemental qualitative analysis by linescan technique across the ceramic/filler interface. There is a precipitation zone close to a dark reaction sublayer (Ti-O compounds), which was formed from the reduction of zirconium oxide by titanium. The interface is enriched in titanium and probably its content increased in the bulk of melted filler alloy as a result of its diffusion from the metallic member. The reaction layer contains elemental $\mathrm{Ti}$ from its diffusion from the coating on the ceramic surface and low EDX levels of the elemental $\mathrm{Ag}$ and $\mathrm{Cu}$ were also found here.

Microstructural analysis at the brazed $\mathrm{ZrO}_{2} / \mathrm{Au}-18 \mathrm{Ni} / \mathrm{Cu}$ joints interface at $980^{\circ} \mathrm{C}$ revealed that $\mathrm{Au}-18 \mathrm{Ni}$ filler alloy was welldiluted close to the metallic member $(\mathrm{Cu}-\mathrm{ETP})$; it was not formed a reaction layer, but just a dark reaction sublayer close to the 
metallized ceramic surface as mentioned before. According to linescan technique results, there was some diffusion of $\mathrm{Ti}$ and $\mathrm{Zr}$ into the bulk of melted filler alloy. Presence of the elemental $\mathrm{Au}$ and $\mathrm{Ni}$, including $\mathrm{Ti}$ were found in this dark layer.
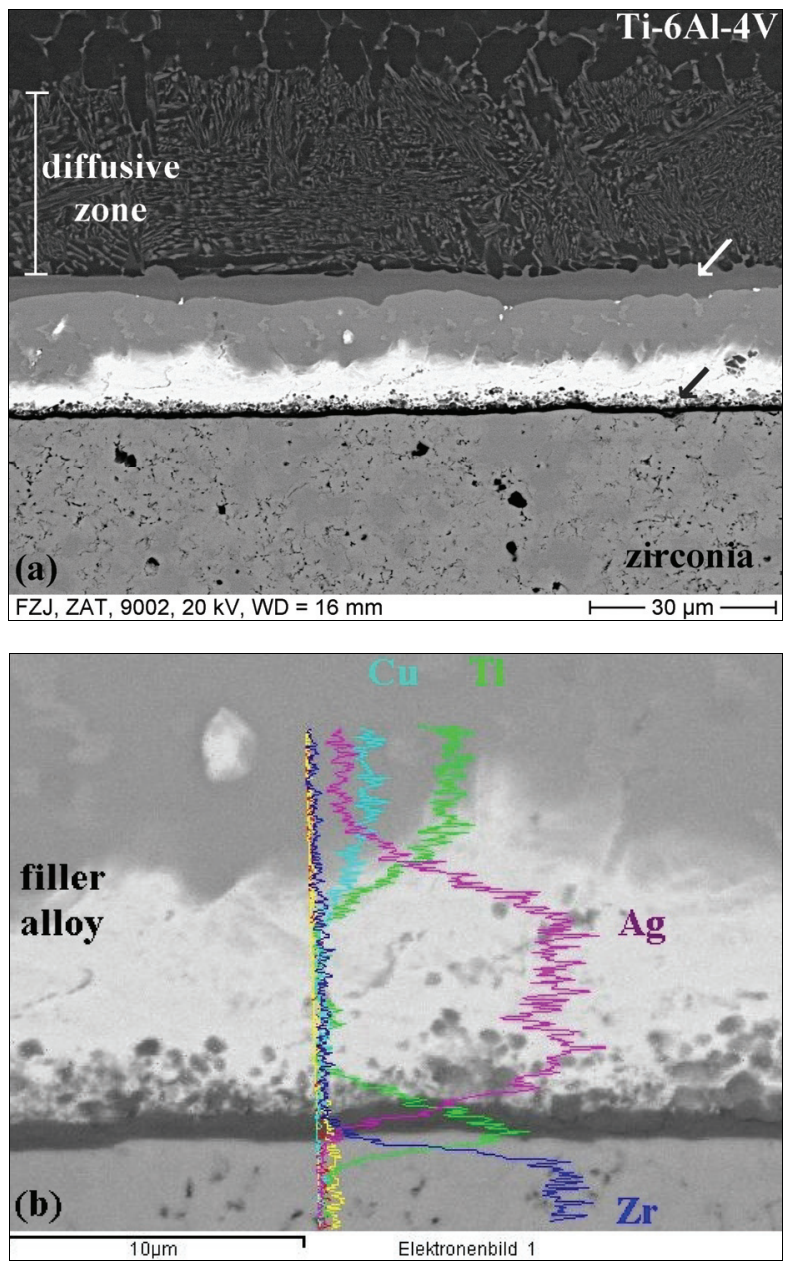

Figure 6. SEM images for $\mathrm{ZrO}_{2} / \mathrm{Ag}-28 \mathrm{Cu} / \mathrm{Ti}-6 \mathrm{Al}-4 \mathrm{~V}$ joint (brazing at $820^{\circ} \mathrm{C}$ ): (a) Reaction layer at the ceramic/filler interface (see gray arrow), diffusive zone in the metallic member and an intermetallic layer at the filler/Ti-6AI4V (see white arrow); (b) Linescan technique across dark reaction sublayer close to the metallized ceramic surface.

SEM images for brazed $\mathrm{ZrO}_{2} / \mathrm{Au}-18 \mathrm{Ni} / \mathrm{Ti}-6 \mathrm{Al}-4 \mathrm{~V}$ joint at $980^{\circ} \mathrm{C}$ are shown in Fig. 7. Microstructure shows a different diffusive zone in the metallic member and excessive formation of intermetallic phases close to the ceramic surface (Fig. 7(a)). EDX analysis by linescan technique detected EDX levels of the elemental $\mathrm{Au}$ and $\mathrm{Ni}$ from the filler alloy in this specified zone. It was noticed in this sample the presence of microcracking at the interface (see Fig. 7(b)). Excessive presence of intermetallics produced in the braze region, thus it may have caused so high residual stresses in the crystalline lattice and subsequent cracking at the filler/ceramic interface probably associated with the CTE mismatch of the individual members to be joined. For instance, some intermetallic phases found here were composed by the following groups: Ti-Au, Ti-Al-Ni-V and Ti-Al-Ni for regions $\mathrm{A}, \mathrm{B}$ and $\mathrm{C}$ shown in Fig. 7(b), respectively. Region $\mathrm{D}$ is a very thin reaction layer $(1-2 \mu \mathrm{m})$ at the filler/ceramic interface that contains elemental $\mathrm{Ti}, \mathrm{Au}$ and $\mathrm{Ni}$, according to EDX analysis. The $\mathrm{Au}-\mathrm{Ti}$ binary system is characterized by a series of well-established compounds, such as $\mathrm{Ti}_{3} \mathrm{Au}, \mathrm{TiAu}_{2}, \mathrm{TiAu}_{4}$ and $\alpha, \beta$ alternating in the $\gamma$-TiAu compound (Nascimento et al., 2007).
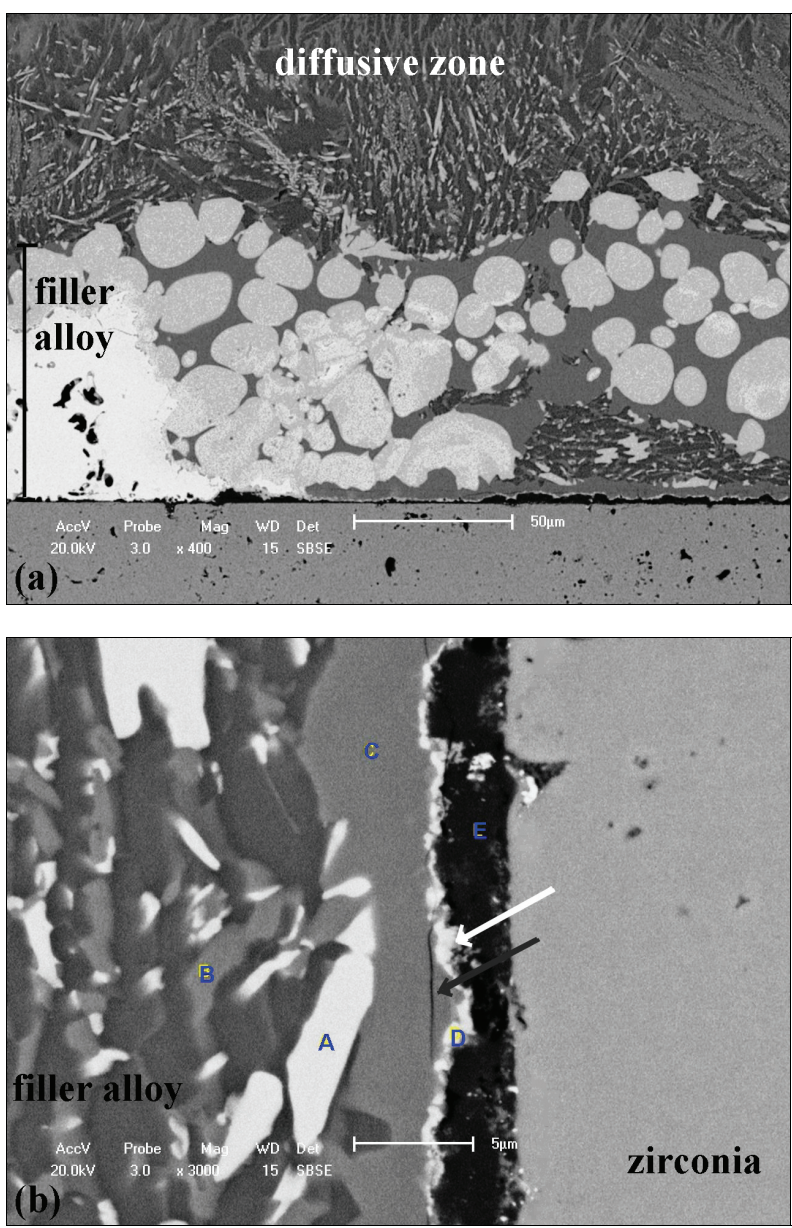

Figure 7. (a) SEM image for $\mathrm{ZrO}_{2} / \mathrm{Au}-18 \mathrm{Ni} / \mathrm{Ti}-6 \mathrm{Al}-4 \mathrm{~V}$ joint (brazing at $980^{\circ} \mathrm{C}$ ); (b) Thin reaction layer at the interface (see white arrow). Punctual EDX analysis in the intermetallic phases and presence of microcracking (see gray arrow). Letters A, B, C and D are indications for EDX analysis.

\section{Darkening Effect in Zirconia Ceramic}

Figure 8 shows the influence of metallic counterparts and $\mathrm{Ti}$ coating from the mechanical metallization technique in the darkening of zirconia ceramics verified close to the brazed ceramic/metal interface. Dark area was more pronounced in PSZ$\mathrm{Mg}$ than TZP-Y ceramic for the same brazing conditions (Ag$28 \mathrm{Cu}$ filler alloy for brazing tests at $820^{\circ} \mathrm{C} / 10 \mathrm{~min}$ ). It was noticed that at higher temperatures, such darkening effect was more extensive from the brazed joint interface, i.e., brazing tests at $880^{\circ} \mathrm{C} / 10$ min using these metallic counterparts and the eutectic $\mathrm{Ag}-28 \mathrm{Cu}$ filler.

Researchers have already reported this typical darkening effect in zirconia at the ceramic/metal joints interface using active brazing process - filler alloys containing $\mathrm{Ti}$ as active metal. This phenomenon is attributed to the formation of a non-stoichiometric zirconia $\left(\mathrm{ZrO}_{2-X}\right.$, where $0<X \leq 0,02$ ), caused by an active metal with high affinity for oxygen (Hanson et al., 2000; Muolo et al., 2004; Smorygo et al., 2007). In other words, there is a partial scavenging of oxygen from the ceramic by titanium, leading to O-deficient area that appears dark (Singh et al., 2007).

The darkening effect of zirconia ceramic from the brazed joint interface can be also influenced by some factors, such as: dwell time at brazing temperature; the substrate to which zirconia is being joined; and the percentage of active metal in the filler composition. There was no damage or significant effect for mechanical strength, 
because of this discoloration region at the joint interface (Hanson et al., 2000; Smorygo et al., 2007).
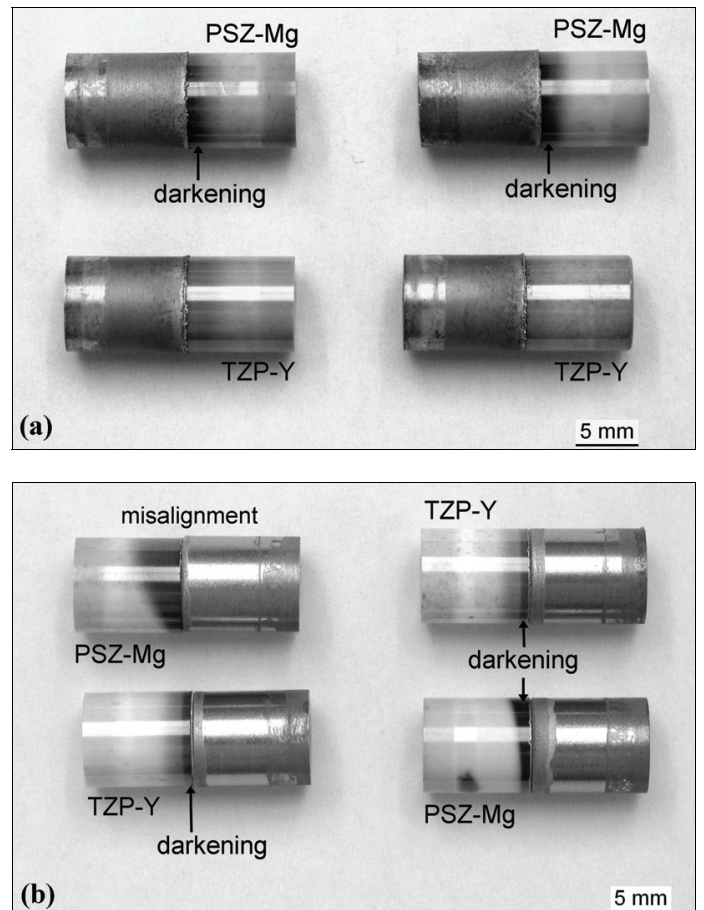

Figure 8. (a) $\mathrm{ZrO}_{2} / \mathrm{Ag}-28 \mathrm{Cu} / \mathrm{Cu}$ joints; (b) $\mathrm{ZrO}_{2} / \mathrm{Ag}-28 \mathrm{Cu} / \mathrm{Ti}-6 \mathrm{Al}-4 \mathrm{~V}$ joints. Darkening effect in zirconia localized from the joint interface for brazing tests at $820^{\circ} \mathrm{C}$.

\section{Microhardness Measurements}

Vickers microhardness profiles across the investigated ceramic/metal interfaces are shown in Fig. 9. The measurements were made under a $200 \mathrm{~g}$ load and loading time of $10 \mathrm{~s}$; indentation was performed on zirconia about $50 \mu \mathrm{m}$ far from the interface. Figures 9(a) and 9(b) show that hardness is only slightly higher inside of the thin approximately braze region than the average hardness of the metallic member. Probably, contents of Ag from the filler contributed for this higher hardness values in the eutectic composition region. Microestructural analysis showed that melted $\mathrm{Ag}-28 \mathrm{Cu}$ filler alloy is well-diluted at the interface with $\mathrm{Cu}$-ETP. However, hardness is notoriously lower within braze region using Ti-6Al-4V as metallic member (see Fig. 9c). Hardness rises rapidly upon entering in ceramic region, which leads to a sharp discontinuity in the microhardness profile at the ceramic/filler interface. Microhardness measurements from the braze region into the depth of zirconia revealed that besides of its typical darkening effect (see previous Fig. 8) there was no negative influence about this mechanical property in the ceramic material.

Figure 10 shows optical micrographs with representative microhardness indentation at the ceramic/metal interface for TZP/Ag$28 \mathrm{Cu} / \mathrm{Cu}-\mathrm{ETP}$ and TZP-Y/Ag-28Cu/Ti-6Al-4V joints for brazing tests at $820^{\circ} \mathrm{C} / 10 \mathrm{~min}$. Microstructure is fairly homogeneous at the $\mathrm{Ag}-$ $28 \mathrm{Cu} / \mathrm{Cu}-\mathrm{ETP}$ interface (see Fig. 10(a)), whose indentation is a little asymmetric in commercially pure copper closely at the interface. The braze region is well-defined for the couple $\mathrm{Ag}-28 \mathrm{Cu} / \mathrm{Ti}-6 \mathrm{Al}-4 \mathrm{~V}$ in Fig. 10b. Microhardness measurement in the braze region was slightly lower than in the bulk of metallic member, probably because of interdiffusion of the elemental $\mathrm{Ag}$ and $\mathrm{Cu}$ from the filler alloy to the metal (see Fig. 10(b)).

J. of the Braz. Soc. of Mech. Sci. \& Eng.
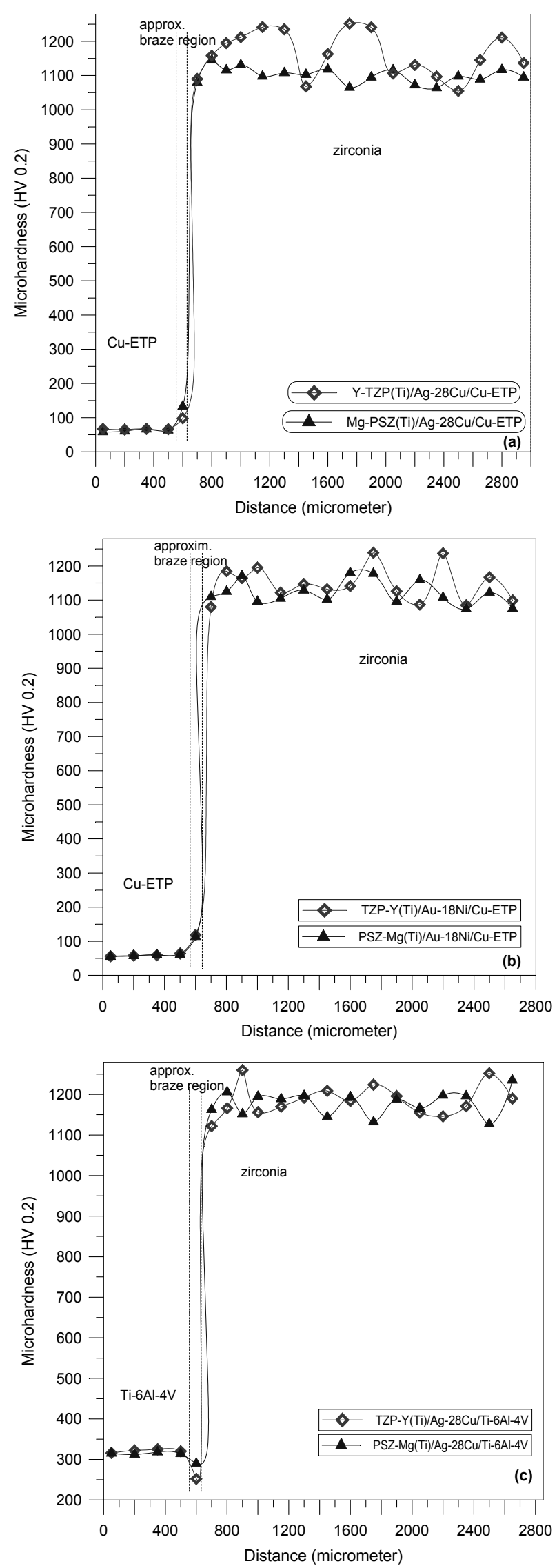

Figure 9. Microhardness profiles across the ceramic/metal interface, (Ti) means titanium mechanical metallization: (a) $\mathrm{ZrO}_{2} / \mathrm{Ag}-28 \mathrm{Cu} / \mathrm{Cu}-\mathrm{ETP}$; (b) $\mathrm{ZrO}_{2} / \mathrm{Au}-18 \mathrm{Ni} / \mathrm{Cu}-\mathrm{ETP}$; (c) $\mathrm{ZrO}_{2} / \mathrm{Ag}-28 \mathrm{Cu} / \mathrm{Ti}-6 \mathrm{Al}-4 \mathrm{~V}$. 

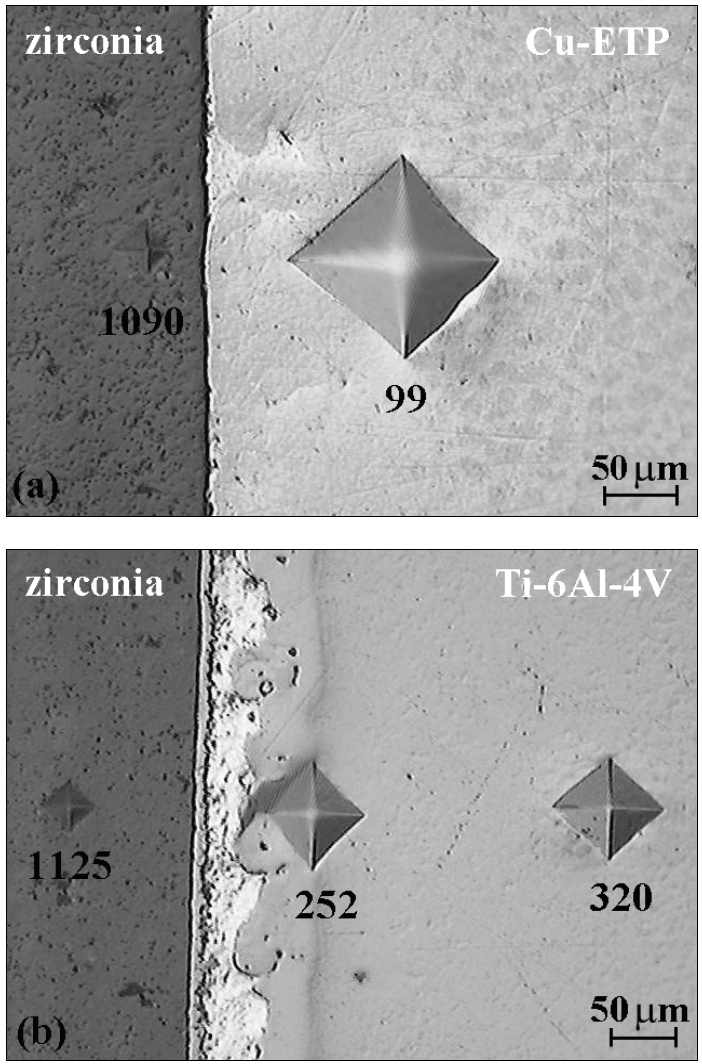

Figure 10. Microhardness indentation $\left(\mathrm{HV}_{0.2}\right)$ at the ceramic/metal interface for brazing at $820^{\circ} \mathrm{C}$ : (a) TZP-Y(Ti)/Ag-28Cu/Cu-ETP; (b) TZP-Y(Ti)/Ag$28 \mathrm{Cu} / \mathrm{Ti}-6 \mathrm{Al}-4 \mathrm{~V}$. (Ti) means metallization with titanium. Magnification 500X.

In addition, residual thermal stresses due to the mismatch among the linear coefficients of thermal expansion (CTE) of the individual components should be also considered. The CTE of Ti$6 \mathrm{Al}-4 \mathrm{~V}\left(9.7 \times 10^{-6}{ }^{\circ} \mathrm{C}^{-1}\right)$ is comparable to the zirconia CTE $(10.0-$ $\left.10.4 \times 10^{-6}{ }^{\circ} \mathrm{C}^{-1}\right)$, but the CTE of Cu-ETP $\left(17.7 \times 10^{-6}{ }^{\circ} \mathrm{C}^{-1}\right)$ and the CTE of filler alloys are higher $-\mathrm{CTE}$ of $\mathrm{Ag}-28 \mathrm{Cu}\left(20-400^{\circ} \mathrm{C}\right)$ and $\mathrm{Au}-18 \mathrm{Ni}\left(20-550^{\circ} \mathrm{C}\right)$ are $17.8 \times 10^{-6}{ }^{\circ} \mathrm{C}^{-1}$ and $14.6 \times 10^{-6}{ }^{\circ} \mathrm{C}^{-1}$, respectively. According to these data, tensile strains can develop at the ceramic/metal interface due to differential contraction during cooling from the brazing temperature. However, it is believed that residual stresses can be accommodate by plastic flow from the large ductility of these fillers (Sciti et al., 2001; Smorygo et al., 2007; Singh et al., 2008).

\section{Conclusion}

Zirconia ceramics were mechanically metallized with titanium and ceramic/metal brazing joints were successfully produced using active-metal-free filler alloys for both Ti-6Al-4V and Cu-ETP as metallic counterparts. Results based on helium gas leak detection were satisfactory with leak rates bellow $10^{-8}$ mbar... $\mathrm{s}^{-1}$, which characterize reliable vacuum tight components. Microestructural analysis at the metallurgically sound joints interface revealed formation of a thin reaction layer and/or precipitation zone associated to a dark sublayer close to the ceramic/filler interface, whose appearance depends on the specific filler alloy and metallic member to be joined. There was chemical interdiffusion between individual components of the joint assembles, which probably led to compositional changes across the joint interface. Excessive presence of intermetallic phases was noticed at the $\mathrm{ZrO}_{2} / \mathrm{Au}-18 \mathrm{Ni} / \mathrm{Ti}-6 \mathrm{Al}-4 \mathrm{~V}$ joints interface, which may have caused high residual stresses in the crystalline lattice associated with the CET mismatch of individual members and subsequent microcracking at the ceramic/filler interface. The darkening effect in zirconia was directly influenced by Ti coating on the ceramic surface, brazing thermal cycles and the used metallic counterparts. Visually, it was a little bit more pronounced in PSZ-Mg ceramic than in TZP-Y ceramic. Microhardness measurements were taken across the joint interface along the darkening region in inner surface of zirconia and there was no measurable negative effect in this mechanical property.

\section{Acknowledgements}

The authors would like to thank the Forschungszentrum Juelich team in Germany for their partnership and technical assistance in this study. J. S. Pimenta acknowledges the Capes/BR-DAAD PROBRAL Project for this international cooperation research and the CNPq agency for granting his doctorate scholarship in Brazil.

\section{References}

Akselsen, O.M., 1992, "Review - Advances in brazing of ceramics", Journal of Materials Science, Vol. 27, pp. 1989-2000.

Elssner, G. and Petzow, G., 1990, "Review - Metal/ceramic joining", ISIJ International, Vol. 30, No. 12, pp. 1011-1032.

Hanson, W.B., Ironside, K.I. and Fernie, J.A., 2000, "Active metal brazing of zirconia", Acta Materialia, Vol. 48, pp. 4673-4676.

Jadoon, A.K., 2004, "Employing reactive synthesis for metal to ceramic joining for high temperature applications", Journal of Materials Science, Vol. 39, pp. 593-604.

Liu, G.W., Li, W., Qiao, G.J., Wang, H.J., Yang, J.F. and Lu, T.J., 2009, "Microstructures and interfacial behavior of zirconia/stainless steel joint prepared by pressureless active brazing", Journal of Alloys and Compounds, No. 470, pp. 163-167.

Muolo, M.L., Ferrera, E. and Morbelli, L., 2004, "Wetting, spreading and joining in the alumina-zirconia-Inconel 738 system", Scripta Materialia, Vol. 50, pp. 325-330.

Nascimento, R.M., 2001, "Metalização mecânica de $\mathrm{Al}_{2} \mathrm{O}_{3}$ para brasagem metal-cerâmica" (In Portuguese), D. Eng. Thesis, Federal University of Santa Catarina, Florianópolis, Brazil, 147 p.

Nascimento, R.M., Buschinelli, A.J.A., Martinelli, A.E., Sigismund, E., Remmel, J., Reisgen, U. and Lugscheider, E., 30Sep-10Oct 2002, "Brazing metals to ceramics mechanically metallized with titanium", Proceedings of the $6^{\text {th }}$ International Conference on Joining Ceramic, Glass and Metal, Munich, Germany, pp. 58-65.

Nascimento, R.M., Martinelli, A.E. and Buschinelli, A.J.A., 2003, "Review Article: Recent advances in metal-ceramic brazing", Cerâmica, Vol. 49, pp. 178-198.

Nascimento, R.M., Martinelli, A.E., Buschinelli, A.J.A. and Sigismund, E., 2007, "Interface microstructure of alumina mechanically metallized with Ti brazed to Fe-Ni-Co using different fillers", Materials Science and Engineering A, No. 466, pp. 195-200.

Schröder, G., Filho, J.C.P. and Schmidt, W., 2000, "Fundamentos de Ensaio de Vazamento e Estanqueidade" (In Portuguese), Reihe Allgemeines/General Band 1, Forschungszentrum Jülich GmbH, Germany, 86 p.

Sciti, D., Bellosi, A. and Esposito, L., 2001, "Bonding of zirconia to superalloy with the active brazing technique", Journal of the European Ceramic Society, Vol. 21, pp. 45-52.

Smorygo, Q., Kim, J.S., Kim, M.D. and Eom, T.G., 2007, "Evolution of the interlayer microstructure and the fracture modes of the zirconia/Cu-AgTi filler/Ti active brazing joints", Materials Letters, Vol. 61, pp. 613-616.

Singh, M., Shpargel, T.P. and Asthana, R., 2007, "Brazing of stainless steel to yttria-stabilized zirconia using gold-based brazes for solid oxide fuel cell applications", International Journal of Applied Ceramic Technology, Vol. 4, No. 2, pp. 119-133.

Singh, M., Shpargel, T.P. and Asthana, R., 2008, "Brazing of yttriastabilized zirconia to stainless steel using $\mathrm{Cu}, \mathrm{Ag}$ and Ti-based brazes", Journal of Materials Science, Vol. 43, No. 2, pp. 23-32. 